\title{
Endophytic bacteria isolated from higher plant in Aceh, Indonesia, and their chemical compounds activity against Fusarium oxysporum f. sp. lycopersici
}

Vina Maulidia', Rina Sriwati ${ }^{2}$, Loekas Soesanto ${ }^{3}$, Syamsuddin ${ }^{4}$, Takahiro Hamaguchi ${ }^{5}$ and Koichi Hasegawa ${ }^{5}$

\begin{abstract}
Background: Endophytic bacteria are an association between bacteria and plant tissue that could play a role as a biocontrol agent.

Main body: Endophytic bacteria were isolated from several high root plants in Aceh, Indonesia. This study aimed to detect the chemical compounds of the potential endophytic bacteria as a biocontrol agent against Fusarium oxysporum f. sp. lycopersici (FOL). There were 198 endophytic bacterial isolates detected in roots of 9 higher plant. The hypersensitive reaction showed that 193 isolated endophytic bacteria were non-pathogenic. There were 13 isolated endophytic bacteria that worked to inhibit FOL between 50.0 and 89.2\%; such endophytic bacteria were isolated from Solanum lycopersicum L., Psidium guajava L., Dendrocalamus asper (Schult with f.) Backer ex Heyne, Pinus merkusii L., Theobroma cacao L., and Albizia chinensis L. Molecular identification using 165 rRNA gene sequence confirmed that the endophytic bacteria were derived from species Pseudomonas aeruginosa, P. mosselii, Arthrobacter sp., Bacillus cereus, B. thuringiensis, and Serratia marcescens. P. aeruginosa that showed the highest inhibition was analyzed using GC-MS analysis. The analysis identified that antibiotics as Pyrrolo [1,2-a]pyrazine-1,4dione, hexahydro-3-(2-methylpropyl)- was produced by P. aeruginosa succeeded in suppressing FOL.

Conclusion: The study recommends the species $P$. aeruginosa, as effective endophytic bacteria for the control of FOL pathogen.
\end{abstract}

Keywords: Endophytic bacteria, Dual culture, Fusarium oxysporum f. sp. lycopersici, Antibiotics, Molecular identification, GC-MS analysis

\section{Background}

Fusarium oxysporum f. sp. lycopersici (FOL) is a plant pathogenic fungus causing Fusarium wilt of tomato. This pathogen causes losses of $50-100 \%$ in crop productions without any effective treatment (Lecomte et al. 2016). Synthetic fungicides have been used for decades to control the plant pathogens as they are affordable and effective. However, the negative impact of the chemical

\footnotetext{
* Correspondence: rinasriwati@unsyiah.ac.id

²Plant Protection Department, Faculty of Agriculture, Universitas Syiah Kuala, Banda Aceh 23111, Indonesia

Full list of author information is available at the end of the article
}

fungicides on environment is also quite serious. Therefore, use of eco-friendly biological control method is a priority task for sustainable agriculture in many countries, protects and increases the antagonistic microorganisms, and reduces damage from pesticides and pathogens. One of the biological methods is by utilizing endophytic bacteria (Abd-Elgawad and Askary 2020).

Endophytic bacteria are capable to colonize inside plant tissues without causing disturbance or harm to host plants. Some of these are known to produce secondary metabolites, which have beneficial roles to the host plants, such as promoting growth, inducing 
protection against infection, and environmental stresses (Eljounaidi et al. 2016). As it has such a positive nature, endophytic bacteria are studied vigorously as potential agents of eco-friendly biological control.

Endophytic bacterium genus Bacillus isolated from Nicotiana glauca plant produced extracellular metabolites which successfully inhibited FOL growth by $87-$ $100 \%$ in vitro. Moreover, these metabolites also protected tomato plant against Fusarium wilt disease and enhanced tomato growth by $38-80 \%$ (Abdallah et al. 2016). Thirty-five isolated bacteria, screened for antagonistic activity in dual culture against fungi Fusarium oxysporum, $P$. aeruginosa showed a high antagonistic activity (58.33\%) (Islam et al. 2018). Twenty-nine bioactive chemical constituents have been identified from methanolic extract of the $P$. aeruginosa by gas chromatogram mass spectrometry (GC-MS). P. aeruginosa produces many important secondary metabolites with high biological activities such as Oxime-,methoxy-phenyl, Edulan II, Methyl-4[nitromethyl]-4- piperidinol, Acetamide, Nmethyl-N-[4-[2-fluoromethyl-1-pyrrolidyl-2-buty, Octahydrochromen-2-one (Altaee et al. 2017).

Based on the previous description, it is necessary to explore and isolate endophytic bacteria derived from some higher plants and performed in vitro testing against wilt Fusarium disease and their chemical compounds to play rules as biocontrol agent. In this study, endophytic bacteria, isolated from 9 higher plants roots, were selected as they were abundant in Aceh, Indonesia, and have great potentials to develop of endophytic bacteria as a biological control agent.

\section{Materials and methods}

\section{Isolation of endophytic bacteria}

Endophytic bacteria were isolated from roots of healthy plants, tomato (Solanum lycopersicum L.), guava (Psidium guajava L.), soybean (Glycine max Merr. L.), bamboo (Dendrocalamus asper (Schult with f.) Backer ex Heyne), sugar cane (Saccharum officinarum L.), pine (Pinus merkusii L), cacao (Theobroma cacao L.), sengon (Albizia chinensis L), and gamal (Gliricidia sepium (Jacq.) Kunth ex Walp.). Samples were collected from several areas of Aceh province, i.e., Banda Aceh, Aceh Besar, and Pidie, Indonesia, using purposive sampling and random sampling. Isolation of endophytic bacteria was performed individually with each plant roots; endophytic bacteria were isolated basically, following the method by Lodewyckx et al. (2002); root samples were cut $(\mathrm{ca} 0.5 \mathrm{~cm})$, washed with sterilized distilled water (DW), and then soaked in running water for $2 \mathrm{~h}$. After washing, root samples were soaked in $5.25 \%$ sodium hypochlorite for $5 \mathrm{~min}$, then rinsed with sterilized DW for $1 \mathrm{~min} 3$ times. The sterilized root samples were grinded in the sterilized mortar and pestle, added to 10 $\mathrm{ml}$ of sterilized DW, then serially diluted from $10^{-1}$ to $10^{-3}$ with sterilized DW. One milliliter of each $10^{-3}$ diluted samples was transferred and spread onto the $\mathrm{Nu}-$ trient Agar (NA) medium and incubated at $28^{\circ} \mathrm{C}$ for 72 h. A total of 198 colonies was isolated and established as candidate strains for further analysis.

\section{Pathogenicity test on tobacco plant}

Bacterial strains streaked on NA medium for $72 \mathrm{~h}$ at 28 ${ }^{\circ} \mathrm{C}$ to isolate a single colony. Colonies were picked up and suspended into the $100 \mathrm{ml}$ of sterilized water. Bacterial suspensions were serially diluted from $10^{-1}$ to $10^{-3}$ (0.281 in OD 600) by sterilized DW, a volume of $1.5 \mathrm{ml}$ of each suspension $\left(10^{-3}\right.$ dilution) as infiltrated into the lamina on abaxial/adaxial side of Nicotiana tabaccum leaves, using a disposable syringe. Pathogenic test to each bacterium was carried out in 3 replicates/plant and repeated 3 times with plant pots. Inoculated tobacco plants were incubated for $72 \mathrm{~h}$ (Nawangsih et al. 2011).

\section{Antagonistic activity of endophytic bacteria}

In vitro antagonistic activity of Fusarium oxysporum $\mathrm{f}$. sp. lycopersici (FOL) test was performed by double culture technique (dual culture) with reference to Suryanto et al. (2011). FOL used in this test was a collection of laboratory plant disease. Endophytic bacteria that incubated for $48 \mathrm{~h}$ scratched straight in the middle of PDA (Potato Dextrose Agar) medium against 168 h FOL was placed adjacent to the bacteria on a Petri dish. Observations were carried out of the inhibition zones (clear zones) produced by endophytic bacteria.

\section{Molecular identification of endophytic bacteria}

A single colony of candidate bacteria was picked up, transferred into the $4 \mathrm{ml}$ of LB broth in 15-ml tube, and cultured for overnight at $28{ }^{\circ} \mathrm{C}$. After culturing, $700 \mu \mathrm{l}$ of each bacterial medium was transferred into a cryotube, mixed with $300 \mu \mathrm{l}$ of $50 \%$ glycerol, and then stored in $80{ }^{\circ} \mathrm{C}$ freezer. Rests of the bacterial medium were centrifuged at $15,000 \mathrm{~g}(14,000 \mathrm{rpm})$ for $5 \mathrm{~min}$ and supernatants were discarded. Genomic DNA from each bacterial palette was extracted, using DNeasy Blood and Tissue Kit (Qiagen, USA), following the instruction manual. Genomic DNA was dissolved in $50 \mu \mathrm{l}$ of TE buffer $\mathrm{pH}$ 8.0. Almost full length of the $16 \mathrm{~S}$ ribosomal RNA gene (ca $1.5 \mathrm{kbp}$ ) was amplified from genomic DNA with the universal primers, 8F (5'-AGA GTT TGA TCC TGG CTC AG-3'), and 1492R (I) (5'-GGT TAC CTT GTT ACG ACT T-3') (Turner et al. 1999). PCR fragments were purified from agarose gel with NucleoSpin ${ }^{\circ}$ Gel and PCR Clean-up (Machery-Nagel, Germany). Samples were submitted to Hokkaido System Science Co. (Sapporo, Japan) for sequencing from both strands using primers, 8F, 1492R (I), 519R (5'-GWA 
TTA CCG CGG CKG CTG-3'), 533F (5'-GTG CCA GCA GCC GCG GTA-3'), 895F (5'CRC GTC GGG AGT RCR G-3'), 907R (5'-CCG TCA ATT CMT TTR AGT TT-3'), and 1237F (5'-GGG CTA CAC ACG YGC WAC-3') (Lane 1991; Weisburg et al. 1991 and Hodkinson and Lutzoni 2009). Sequence results were deposited in NCBI GenBank (https://submit.ncbi.nlm.nih.gov/ subs/?search=SUB7518780). The MEGA 7.0 program was used to construct phylogenetic trees by maximum likelihood (ML) methods with 1000 iterations (Felsenstein 1985).

\section{GC-MS analysis}

The extract obtained from the mentioned procedure was then sent for analysis by gas chromatography-mass spectroscopy (GC-MS) in LIPI, Bogor, Indonesia. The gas chromatography- mass spectroscopy had been carried out on TRACE 1300 GC, TSQ 8000 TRIPLE QUADRUPOLE MS fitted with TG $5 \mathrm{MS}(30 \mathrm{~m} \times 0.25 \mathrm{~mm}, 0.25 \mu \mathrm{m})$ column and S/SL Injector. The injector temperature had been kept at $250{ }^{\circ} \mathrm{C}$ and MS transfer line temperature had been kept at $250{ }^{\circ} \mathrm{C}$ along with ion source temperature, also $250{ }^{\circ} \mathrm{C}$. The column temperature had been programmed between 60 and $250{ }^{\circ} \mathrm{C}$ at $10^{\circ} \mathrm{C} / \mathrm{min}$ using helium as carrier gas at a carrier flow rate of $1 \mathrm{ml}$ $\mathrm{min}^{-1}$. Injection volume had $1.0 \mu \mathrm{l}$ prepared in DMSO having split flow $1 \mathrm{ml} \mathrm{min}^{-1}$. The mass spectra had been taken at $75 \mathrm{eV}$ with mass scan range from $\mathrm{m} / \mathrm{z}$ 40-500 $\mathrm{amu}$. The individual constituents had been identified by comparing their mass spectra with those of standard using NIST (National Institute of Standards and Technology, US Department of Commerce) compounds (Sparkman et al. 2011).

\section{Results and discussion}

\section{Isolation of endophytic bacteria}

The results were obtained from the stages of the exploration, isolation, and purification of bacteria. There were 26 endophytic bacteria isolated from $D$. asper (Schult with f.) Backer ex Heyne) plant root, 21 from G. max Merr. L., 25 from S. officinarum L., 19 from T. cacao L., 21 from A. chinensis L., 21 from $P$. merkusii L., 26 from G. sepium ((Jacq.) Kunth ex Walp.), 18 from P.gajava L., and 21 from S. lycopersicum L. The total number of isolated endophytic bacterial was 198 isolates. Almost all endophytic bacteria that infected higher plants could be isolated from the roots or other parts of the plant. This research finding was supported by Yuan et al. (2015). Eighty-two endophytic bacteria were isolated from bamboo root, rhizome, stem, and leaves. Zhao et al. (2018) found 276 endophytic bacteria isolated from root nodules of soybean. Arthee and Marimuthu (2017) isolated 22 endophytic bacteria from root and stem of sugar cane. Also, Konate et al. (2015) isolated 24 endophytic bacteria from cacao roots. Furthermore, Manikandan et al. (2016) isolated 54 endophytic bacteria from roots and stems of A. lebbeck. Abbamondi et al. (2016) recorded 23 endophytic bacteria isolated from tomato roots.

\section{Pathogenicity test on tobacco plant}

Based on the results of isolation, from 198 isolates, 5 endophytic bacteria were shown as pathogens. Three isolates endophytic bacteria from G. maculata plant root and 2 from $S$. lycopersicum plant roots showed the necrosis symptoms. These 5 isolates could not be used at further experiment because they showed pathogenic activity. Hundred and ninety-three isolates endophytic bacteria were nonpathogenic bacteria without showing necrotic symptom.

Tobacco plants were used as an indicator for hypersensitive testing. The hypersensitive response was indicated by the occurrence of browning on the area inoculated by bacteria. The browning indicated the death of local leaf tissue (necrosis). Hypersensitivity reaction (HR) was expressed as positive $(+)$ when necrotic symptoms were formed on leaf tissue, while unchanged leaf tissue was negatively (-) reacted (Umesha et al. 2008). Nawangsih et al. (2011) reported that there were 49 endophytic bacteria isolated from the tomato plant root, and 8 showed chlorotic or necrotic zones when injected in tobacco leaves.

\section{Antagonistic activity of endophytic bacteria}

Pathogenicity test founded 193 isolates. The result of antagonistic activity test showed that there were 13 isolates showed activity $>50 \%$ in suppressing FOL. The percentage of inhibition of endophytic bacteria isolated from guava root $\left(\mathrm{AJ}_{14}\right)$ were the highest activity to FOL (87.30\%), isolate from bamboo showed $60.20 \%$, and all other isolates showed $50 \%$ inhibition activity (Table 1 ). Twenty-five isolates of endophytic bacteria from sugarcane roots were not able to inhibit FOL; otherwise, there were isolates from the pine, cacao, and sengon roots that had an average moderate inhibition (50\%). Endophytic bacteria isolated from tomato also had the highest inhibition activity (ranged from 83.3 to $80.2 \%$ ), moderate around $50 \%$.

Inhibition of endophytic bacteria to FOL was estimated by the ranges of inhibition activity following Soytong (1988). The activity $>75 \%$ was the highest one, followed by $60-75 \%$ a high inhibition, and $50-60 \%$ was a moderate inhibition, then $<50 \%$ was a low inhibition and (-) indicated no inhibition activity. Results of inhibition activity test indicated that 13 isolates showed activity $>50 \%$ in suppressing FOL (Table 1 ).

Endophytic bacteria had a potential effect on suppressing the growth of pathogenic fungi by producing 
Table 1 Percentage of antagonistic activity of 13 endophytic bacteria in suppressing Fusarium oxysporum f. sp. lycopersici (FOL)

\begin{tabular}{llll}
\hline No. & Host plant & Isolated code & Percentage isolates against FOL (\%) \\
\hline 01 & S. lycopersycum L. & $\mathrm{AM}_{02}$ & 83.3 \\
02 & S. lycopersycum L. & $\mathrm{AM}_{08}$ & 50.0 \\
03 & S. Iycopersycum L. & $\mathrm{AM}_{14}$ & 80.2 \\
04 & P. gajava L. & $\mathrm{AJ}_{01}$ & 50.6 \\
05 & P. gajava L. & $\mathrm{AJ}_{14}$ & 89.2 \\
06 & P. gajava L. & $\mathrm{AJ}_{18}$ & 87.3 \\
07 & P. merkusii L. & $\mathrm{AP}_{04}$ & 50.2 \\
08 & P. merkusii L. & $\mathrm{AP}_{12}$ & 50.9 \\
09 & P. merkusii L. & $\mathrm{AP}_{17}$ & 50.2 \\
10 & D. asper (Schult with f.) Backer ex Heyne & $\mathrm{AB}_{06}$ & 60.2 \\
11 & D. asper (Schult with f.) Backer ex Heyne & $\mathrm{AB}_{18}$ & 50.2 \\
12 & A. chinensis L. & $\mathrm{AS}_{09}$ & 50.3 \\
13 & T. cacao L. & $\mathrm{AK}_{08}$ & 50.7 \\
\hline
\end{tabular}

secondary metabolites, such as antibiotic, enzyme, hormone, toxins, and volatile compounds, and could be a source of plant resistance. The process of inhibiting endophytic bacteria on the growth of pathogenic fungi caused by several factors, such as space and nutritional competition, antibiotic compounds, and lytic enzymes produced to inhibit the growth of pathogens and to provide resistance to plants (Maksimov et al. 2018).

Strain B. amyloliquefaciens was able to produce secondary metabolites (iturin and bacillomycin D), which effectively inhibited F. oxysporum (Wang et al. 2016). There were 300 strains of bacterial antagonists isolated from South Korean mining soils that were filtered using multiple culture tests; there were 2 potential antagonistic strains found: $P$. aeruginosa and B. stratosphericus; both strains were optimal in inhibiting the mycelial growth of
Fusarium sp. (Durairaj et al. 2018). According to Altaee et al. (2017), P. aeruginosa was able to inhibit 50\% Fusarium sp. Under the present study, both Pseudomonas and Bacillus species were found as endophytic bacteria that could affect the growth of Fusarium mycelial growth.

\section{Molecular identification of endophytic bacteria}

Through this study, 13 endophytic bacterial isolates that had the potential as biocontrol agents against FOL pathogens were identified molecularly, using 16S rRNA (Table 2) and 4 bacterial genera, i.e., Pseudomonas, Bacillus, Arthobacter, and Serretia were obtained. Endophytic bacteria isolated from tomato roots were $P$. aeruginosa and Arthrobacter sp., from guava roots was $P$. aeruginosa, from pine roots were $P$. aeruginosa and

Table 2 Sequencing DNA from 13 endophytic bacteria isolates

\begin{tabular}{llllll}
\hline No. & Isolate code & Species & Plant & Assession No. & Length of DNA fragment \\
\hline 01 & $\mathrm{AM}_{02}$ & P. aeruginosa & S. lycopersycum L. & MT598016 & $1.431 \mathrm{bp}$ \\
02 & $\mathrm{AM}_{08}$ & Arthrobacter sp. & S. lycopersycum L. & MT598017 & $454 \mathrm{bp}$ \\
03 & $\mathrm{AM}_{14}$ & P. aeruginosa & S. lycopersycum L. & MT598018 & $1.423 \mathrm{bp}$ \\
04 & $\mathrm{AJ}_{01}$ & P. aeruginosa & P. gajava L. & MT598019 & $1.294 \mathrm{bp}$ \\
05 & $\mathrm{AJ}_{14}$ & P. aeruginosa & P. gajava L. & MT598020 & $1.430 \mathrm{bp}$ \\
06 & $\mathrm{AJ}_{18}$ & P. aeruginosa & P. gajava L. & MT598021 & $1.433 \mathrm{bp}$ \\
07 & $\mathrm{AP}_{04}$ & P. aeruginosa & P. merkusii L. & MT598022 & $1.420 \mathrm{bp}$ \\
08 & $\mathrm{AP}_{12}$ & B. cereus & P. merkusii L. & MT598023 & $1.465 \mathrm{bp}$ \\
09 & $\mathrm{AP}_{17}$ & P. aeruginosa & P. merkusii L. & MT598024 & $1.448 \mathrm{bp}$ \\
10 & $\mathrm{AB}_{06}$ & P. moselii & D. asper (Schult with f.) Backer ex Heyne & MT598025 & $1.424 \mathrm{bp}$ \\
11 & $\mathrm{AB}_{18}$ & P. aeruginosa & D. asper (Schult with f.) Backer ex Heyne & MT598026 & $1.446 \mathrm{bp}$ \\
12 & $\mathrm{AS}_{09}$ & S. marcescens & A. chinensis L. & MT598027 & $1.410 \mathrm{bp}$ \\
13 & $\mathrm{AK}_{08}$ & B. thuringiensis & T. cacao L. & MT598028 & $1.454 \mathrm{bp}$
\end{tabular}


B.cereus, from bamboo roots were $P$. moselii and P. aeruginosa, from sengon roots was $S$. marcescens, and from cacao roots was $B$. thuringiensis. A phylogenetic tree constructed, using 16S rRNA sequences of the suspected endophytic bacteria isolates related taxa, was generated by the maximum likelihood method (presented in Fig. 1).

Egamberdieva et al. (2017) reported that endophytic bacterial isolates from Cicer arietinum L. plant roots and identified using $16 \mathrm{~S}$ rRNA as B. cereus, B. subtilis, and $B$. thuringiensis were able to inhibit the pathogen $F$. oxysporum. Based on the research of Bredow et al. (2015), endophytic bacteria associated with coffee plant (Coffea arabica), sugar cane (Saccharum officinarum), bean (Pisum sativum), corn (Zea mays L.), soybean (Glycine max.), tomato (S. lycopersicum), and grape (Vitis venifera L.) analyzed using 16S rRNA showed that Bacillus, Pseudomonas, and Mycobacterium were the most common genera that colonized these plants. Arthee and Marimuthu (2017) reported that Bacillus sp. and
Burkholderia sp. were identified using 16S rRNA as endophytic bacteria in sugarcane plant. Yuan et al. (2015) stated that Arthrobacter, Staphylococcus, Bacillus, and Enterobacter were the dominant bacterial strains as endophytic bacteria that colonized bamboo plant. Obtained results were compatible with that reported by these workers and shared the same types of bacterial species, such as the genera Bacillus, Pseudomonas, and Serretia which were dominantly present from isolation in plant roots (Table 2).

\section{GC-MS analysis}

Methanolic extraction was characterized and identified by GC-MS analysis. The interpretation on mass spectrum GC-MS was conducted using the database of National Institute Standard and Technology (NIST) having more than 62,000 patterns. The spectrum of the unknown component was compared with the spectrum of the known components stored in the NIST library. The active principles with their retention time (Rt),

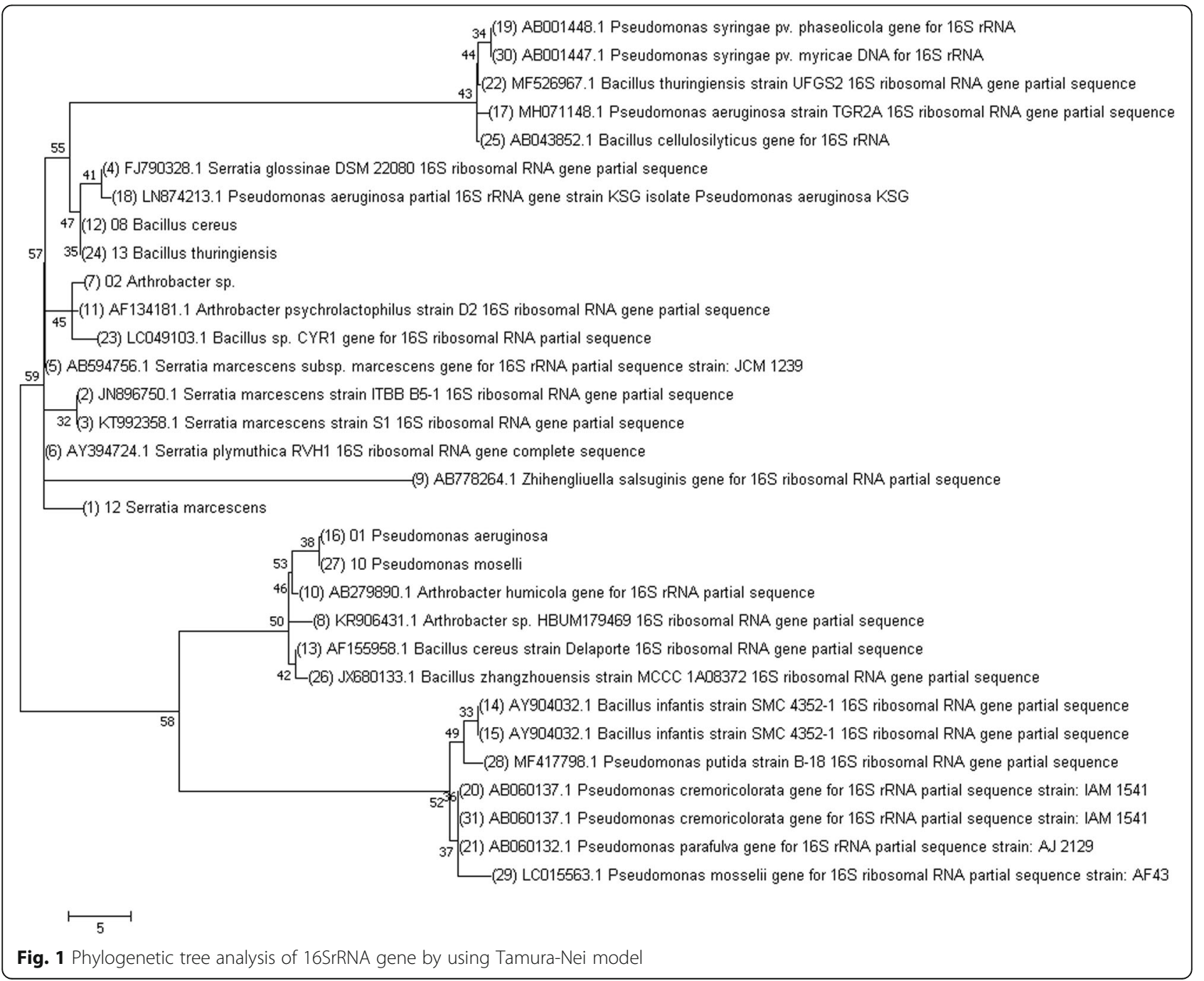




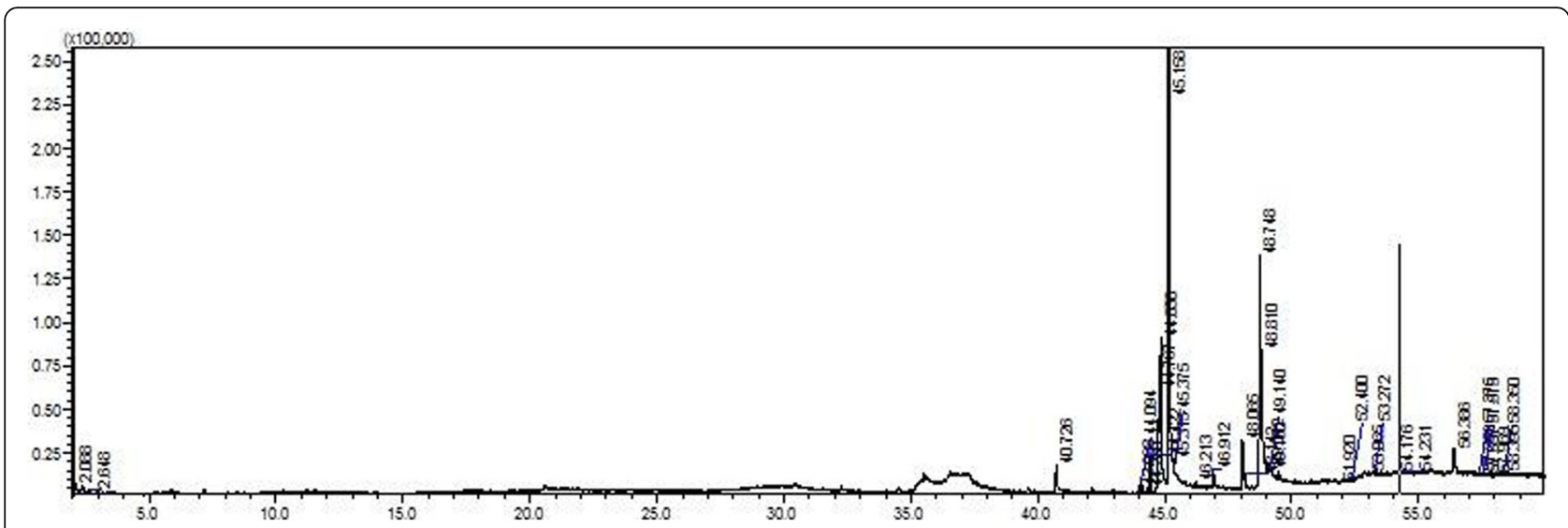

Fig. 2 GC-MS chromatogram of methanol extract of Pseudomonas aeruginosa

molecular formula, molecular weight, and concentration percentage (area \%) are represented in Fig. 2. The major compounds in GC-MS analysis of $P$. aeruginosa was Pyrrolo [1,2-a]pyrazine-1,4-dione, hexahydro-3-(2methylpropyl)- (0.33\%).

\section{Conclusion}

One-hundred and ninety-eight isolates were isolated from 9 higher plants in Aceh, Indonesia. Thirteen of them were able to inhibit FOL at moderate and high rates. The 13 isolates were identified using $16 \mathrm{~S}$ rRNA. One of the bacterial strains isolated from guava root $(P$. aeruginosa) achieved $89.2 \%$ inhibition and showed a superior ability to inhibit FOL.

\section{Abbreviations}

FOL: Fusarium oxysporum f. sp. Iycopersici; 16S rRNA: 165 ribosomal ribonucleic acid; GC-MS: Gas chromatogram mass spectrometry; DW: Distilled water; NA: Nutrient agar; OD: optical density; LB: Lysogeny Broth; DNA: Deoxyribonucleic acid; PCR: Polymerase chain reaction; NCBI: National Center for Biotechnology Information; ML: Maximum likelihood; DMSO: Dimethyl sulphoxide; NIST: National Institute of Standards and Technology; TSQ: Thermo Scientific Gas; TG: Thermo gravimetric

\section{Acknowledgements}

The authors are gratefully thankful to Ministry Research, Technology and Higher Education of Republic of Indonesia which has supported this research under Program of Masters Towards Doctorates for Excellent Bachelors (PMDSU) and Quality Improvement of International Publication (PKPI) scheme No. 71/UN11.2/PP/SP3/2018. We thank Hasegawa laboratory of Chubu University, Japan, and Plant Disease laboratory Assistance of Universitas Syiah Kuala, Indonesia, and all laboratory members for helping authors to conduct this research.

\section{Authors' contributions}

The concept and design of the experiments were prepared by all authors. VM conducted the experiments, analyzed the results, and wrote the manuscript. TH and $\mathrm{KH}$ performed the experiments and analyzed the data. $\mathrm{RS}, \mathrm{LS}, \mathrm{S}$, and $\mathrm{KH}$ conceived the experiment and wrote and verified the manuscript. All authors have read and approved the manuscript.

\section{Funding}

This work was granted by Ministry Research, Technology and Higher Education of Republic of Indoesia under Program of Masters Towards Doctorates for Excellent Bachelors (PMDSU) for supported all academic and research scholarship and Programs Quality Improvement of International
Publications (PKPI) scheme No. 71/UN11.2/PP/SP3/2018 in supported collaboration research with Chubu University Japan.

\section{Availability of data and materials \\ Not Applicable.}

\section{Ethics approval and consent to participate}

This manuscript is written in accordance with the guidelines for the authors available at journal website. In addition, this work has never been published before and now approved by all authors and host authorities.

\section{Consent for publication \\ Not Applicable.}

\section{Competing interests}

No potential conflict of interest was reported by the authors.

\section{Author details}

${ }^{1}$ Doctoral Program of Agricultural Sciences, Faculty of Agriculture, Universitas Syiah Kuala, Banda Aceh 23111, Indonesia. ${ }^{2}$ Plant Protection Department, Faculty of Agriculture, Universitas Syiah Kuala, Banda Aceh 23111, Indonesia. ${ }^{3}$ Agrotechnology Department Faculty of Agriculture, Jenderal Soedirman University, Purwokerto 53123, Indonesia. ${ }^{4}$ Agrotechnology Department, Faculty of Agriculture, Universitas Syiah Kuala, Banda Aceh 23111, Indonesia. ${ }^{5}$ Department of Environmental Biology, College of Bioscience \&

Biotechnology, Chubu University, 1200 Matsumoto, Kasugai, Aichi 487-8501, Japan.

Received: 10 July 2020 Accepted: 4 February 2021

Published online: 12 February 2021

\section{References}

Abbamondi GR, Tommonaro G, Weyens N, Thijs S, Sillen W, Gkorezis P, lodice C, de Melo RW, Nicolaus B, Vangronsveld J (2016) Plant growth-promoting effects of rhizospheric and endophytic bacteria associated with different tomato cultivars and new tomato hybrids. Chem Biol Technol Agric 3(1):110. https://doi.org/10.1186/s40538-015-0051-3

Abdallah ABR, Mokni-Tlili S, Nefzi A, Jabnoun-Khiareddine H, Daami-Remadi M (2016) Biocontrol of Fusarium wilt and growth promotion of tomato plants using endophytic bacteria isolated from Nicotiana glauca organs. Biol Control 97:80-88. https://doi.org/10.1016/j.biocontrol.2016.03.005

Abd-Elgawad MMM, Askary TH (2020) Factors affecting success of biological agents used in controlling the plant-parasitic nematodes. Egypt J Biol Pest Control 30:1-11. https://doi.org/10.1186/s41938-020-00215-2

Altaee N, Kadhim MJ, Hameed IH (2017) Detection of volatile compounds produced by Pseudomonas aeruginosa isolated from UTI patients by gas chromatography-mass spectrometry. IJTPR 8(6):462-470. ISSN: 0975-5160.

Arthee R, Marimuthu P (2017) Studies on endophytic Burkholderia sp. from sugarcane and its screening for plant growth promoting potential. J Exp Biol Agric Sci 5(2):242-257. https://doi.org/10.18006/2017.5(2).242.257 
Bredow C, Azevedo JL, Pamphile JA, Mangolin CA, Rhoden SA (2015) In silico analysis of the $16 \mathrm{~S}$ rRNA gene of endophytic bacteria, isolated from the aerial parts and seeds of important agricultural crops. Genet Mol Res 14: 9703-9721. https://doi.org/10.4238/2015.August.19.3

Durairaj K, Velmurugan P, Park JH, Chang WS, Park YJ, Senthilkumar P, Choi KM, Lee JH, Oh BT (2018) Characterization and assessment of two biocontrol bacteria against Pseudomonas syringae wilt in Solanum lycopersicum and its genetic responses. Microbiol Res 206:43-49. https://doi.org/10.1016/j.micres.2 017.09.003

Egamberdieva D, Wirth SJ, Shurigin W, Hashem A, Abdallah EF (2017) endophytic bacteria improve plant growth, symbiotic performance of chickpea (Cicer arietinum L.) and induce suppression of root rot caused by fusarium solani under salt stress. Front Microbiol 8:1-13. https://doi. org/10.3389/fmicb.2017.01887

Eljounaidi K, Lee SK, Bae H (2016) Bacterial endophytes as potential biocontrol agents of vascular wilt diseases - review and future prospects. Biological Control 103:62-68. https://doi.org/10.1016/j.biocontrol.2016.07.013

Felsenstein J (1985) Confidence limits on phylogenies: an approach using the bootstrap. Evolution 39:783-791. https://doi.org/10.1111/j.1558-5646.1985. tb00420.x

Hodkinson BP, Lutzoni F (2009) A microbiotic survey of lichen-associated bacteria reveals a new lineage from the rhizobiales. Symbiosis 49:163-180

Islam MA, Nain Z, Alam MK, Banu NA, Islam MR (2018) In vitro study of biocontrol potential of rhizospheric Pseudomonas aeruginosa against Fusarium oxysporum f. sp. cucumerinum. Egypt J Biol Pest Control 28:1-12. https://doi. org/10.1186/s41938-018-0097-1

Konate I, Ouattara A, Coulibaly B, Guei RNK, Amani K, Kouadio Kl, Filali-Maltouf A, Koffi M (2015) Phenotypic diversity of associative bacteria isolated from roots and stems of cacao (Theobroma cacao) Tree in Daloa, Côte d Ivoire. Int J Curr Microbiol App Sci 114(9):560-570. ISSN: 2319-7706

Lane DJ (1991) In: Stackebrandt E, Goodfellow M (eds) 16S/23S rRNA sequencing. In: Nucleic acid techniques in bacterial systematics, vol 205. Wiley, New York, pp 115-175

Lecomte C, Alabouvette C, Edel-Hermann V, Robert F, Steinberg C (2016) Biological control of ornamental plant diseases caused by Fusarium oxysporum : A review. Biological Control 101:17-30. https://doi.org/10.1016/j. biocontrol.2016.06.004

Lodewyckx C, Vangronsveld J, Porteous F, Moore ERB, Taghavi S, Mezgeay M, Lelie DDV (2002) Endophytic bacteria and their potential applications. Crit Rev Plant Sci 21(6):583-606. https://doi.org/10.1080/0735-26029104437

Maksimov IV, Maksimova TI, Sarvarova ER, Blagova DK, Popov VO (2018) Endophytic bacteria as effective agents of new-generation biopesticides (Review). Appl Biochemi Microbiol 54:128-140. https://doi.org/10.1134/S0003 683818020072

Manikandan M, Kannan V, Mendoza OH, Kanimozhi M, Chun S, Pašić L (2016) The contribution of endophytic bacteria to Albizia lebbeck mediated phytoremediation of tannery effluent contaminated soil. Int J Phytoremediation 18:77-86. https://doi.org/10.1080/15226514.2015.1064351

Nawangsih AA, Damayanti I, Wiyono S, Kartika JG (2011) Selection and characterization of endophytic bacteria as biocontrol agents of tomato bacterial wilt disease. Hayati J Biosci 18:66-70. https://doi.org/10.4308/ hjb.18.2.66

Soytong K (1988) Identification of species of chaetomium in the Philippines and screening for their biocontrol properties against seed borne fungi of rice. Ph.D. Thesis. Dept. PlantPathology, ULPB, College, Laguna, Philippines.

Sparkman OF, Zelda P, Fulton GK (2011) Gas chromatography and mass spectrometry: a practical guide. Academic Press, United States. ISBN: 9780123736284.

Suryanto D, Irawati N, Munir E (2011) Isolation and characterization of chitinolytic bacteria and their potential to inhibit plant pathogenic fungi. Microbiol Indonesia 5:144-148. https://doi.org/10.5454/mi.5.3.8

Turner S, Pryer KM, Miao VPW, Palmer JD (1999) Investigating deep phylogenetic relationships among cyanobacteria and plastids by small subunit rRNA sequence analysis. J Eukaryot Microbiol 46:327-338

Umesha S, Richardson PA, Kong P, Hong CX (2008) A novel indicator plant to test the hypersensitivity of phytopathogenic bacteria. J Microbiol Methods 72:95-97. https://doi.org/10.1016/j.mimet.2007.11.002

Wang Y, Yang C, Yao Y, Wang Y-q, Zhang Z, Xue L (2016) The diversity and potential function of endophytic bacteria isolated from Kobreasia capillifolia at alpine grasslands on the Tibetan Plateau, China. J Integr Agric 15:21532162. https://doi.org/10.1016/S2095-3119(15)61248-5

Weisburg WG, Barns SM, Pelletier DA, Lane DJ (1991) 16S ribosomal DNA amplification for phylogenetic study. J Bacteriol 173:697-703

Yuan ZS, Liu F, Zhang GF (2015) Isolation of culturable endophytic bacteria from moso bamboo (Phyllostachys edulis) and 16S rDNA diversity analysis. Arch Biol Sci 67:1001-1008. https://doi.org/10.2298/ABS141212063Y

Zhao L, Xu Y, Lai X (2018) Antagonistic endophytic bacteria associated with nodules of soybean (Glycine max L.) and plant growth-promoting properties. Braz J Microbiol 49:269-278. https://doi.org/10.1016/j.bjm.2017.06.007

\section{Publisher's Note}

Springer Nature remains neutral with regard to jurisdictional claims in published maps and institutional affiliations.

\section{Submit your manuscript to a SpringerOpen ${ }^{\circ}$ journal and benefit from:}

- Convenient online submission

- Rigorous peer review

- Open access: articles freely available online

- High visibility within the field

- Retaining the copyright to your article

Submit your next manuscript at $\boldsymbol{\nabla}$ springeropen.com 